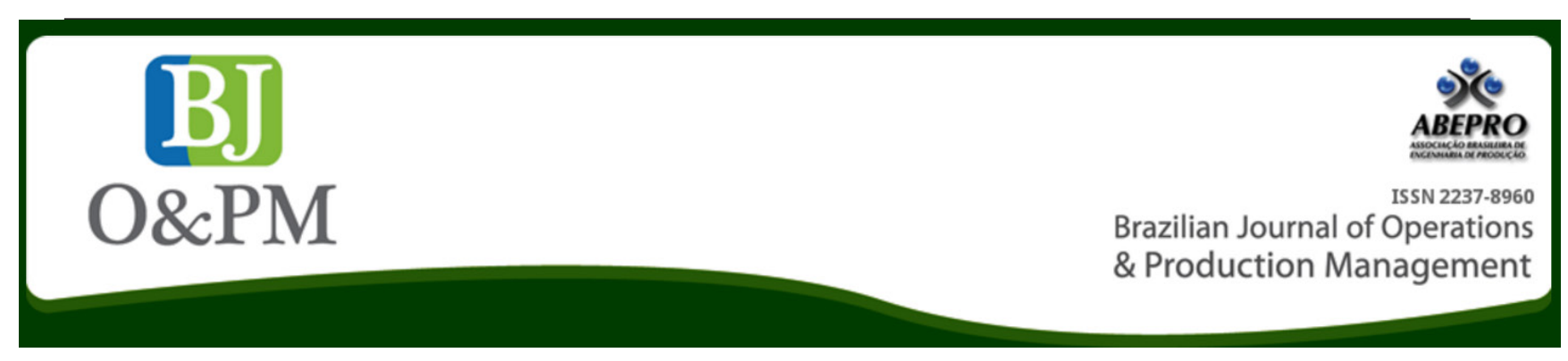

\title{
POWERING CUSTOMER CONNECTIVITY OF PRODUCTS WITH LAST MILE SUPPORT SERVICES: EVIDENCES FROM INDIAN PASSENGER CAR MANUFACTURING
}

\author{
Sumeet Singh Jasiala; S S Pala; Sanjeev Bansal ${ }^{a}$
}

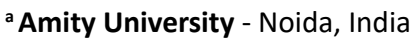

\begin{abstract}
The paper highlights post-production customer connectivity processes in an automobile manufacturing set-up. Identity of post-production processes has been established as a unique in company service operations or pseudo-manufacturing activities. Consequently this research observes that handling these activities purely with a manufacturing focus or with a pure service focus would not be that effective. This paper in-turn proposes a new approach to powering the customer connectivity process in the last mile of a product's journey from manufacturing to market. The scenario has been addressed in three domains, viz., Post-Production pre-market functions, Product Installation, and Product Liabilities. Through a composite process map of the post-production situations it captures the order winning elements to pick up opportunities for the possible reinforcement of adding value for money in the last mile activities on the product from company to customer.
\end{abstract}

Key Words: Pre-market functions; Automobile manufacturing; Quality assurance; Servitisation. 
Brazilian Journal of Operations \& Production Management

Volume 14, Número 1, 2017, pp. 126-135

DOI: 10.14488/BJOPM.2017.v14.n1.a14

\section{INTRODUCTION}

Products are brought about as proposed solution to a problem that a customer has at hand. This solution is a specific capability. Product quality is practically an index of this capability that lies encapsulated in the product. Whereas the physical part of the product is perceivable by sensory means; the perception of solution-capability of a product is experiential. Therefore, it should be essential for presenting and assuring this solution-capability of the product to the customer more carefully to strengthen its customer-connect. What comes out in the factories at the end of a production sequence as a carrier of the capability completes only a part of the overall intention cycle. The complementary part of the cycle includes taking the product thence to the customer where the capability changes hand for a price and is put to use. How a product reaches the customer and how it remains in use become therefore the other profound considerations for speaking about its quality. This paper inquires on this twin issues for improving the customer connectivity of the product as a customer-end solution provider to a specific problem.

The passenger car has graduated from the core product of four tyre, engine, steering system and a body too much complex augmented term like Multi-point Fuel Injection (MPFI) engines, Mapped Exhaust Gas Re-circulation (EGR), Variable valve-train system and light off technology. The competition has moved from three cars on a road to averagely eight cars per segment. The real survival question has germinated into the new form. Customer wants value for money as a common denominator, while quality remains the unsaid must-comply norm. All the players are trying to give their best in both the final product and processes involved therein. The question "How good is the best?" becomes pertinent.

There is, however, growing support for quality to be closely associated with customer demands. The modern-day quality concept rejects the traditional notion of quality as being the degree of conformance to a standard or measurement of workmanship. The Japanese concept of quality (Sohal, et al.,1989) hinges on the product's fitness for use and the degree of customer satisfaction derived from using that product. In other words, it is not the product manufacturer but the customer who determines whether or not quality has been achieved. The goal is to achieve continuous quality improvement that permeates every process, every product and every service in organization (Dingus, 1988). The ultimate measurement of a product's value is that of the service it provides to its user. The quality of a product is also defined by its working condition when it arrives at customer's site (Steeples, 1992). It is also measured by the reliability the product shows during its expected useful life. But very few companies define quality by the level of customer satisfaction achieved when the product is used. Customer satisfaction as an index of a product's quality covers two important areas:-

a) The actual performance of a product compared against the 'expectations' fostered in a customer's mind during the selling process.

b) The level of customer support provided after the delivery of the product.

As for example, some useful customer satisfaction determinants have been seen to include:

I. Dead on Arrival (DoA): The DoA rate refers to the percentage of products shipped that do not work when they arrive at customer's site. In some occasions, the customer receives a product, it gets installed but it does not work. The total quality concept calls DoA anything that makes the product different from what the customer expected when it was ordered (Hernamdez, 1993). A company with a perfectquality programme should have a zero DoA rate.

II. Infantile Mortality and Mean Time between Failures (MTBF): Infantile mortality is defined as a malfunction of the product within a short period of time after installation and initial usage. Infantile mortality is usually a measurement of quality of the components used to build the product and a reflection of the process capability.

III. Mean Time between Service Calls (MTBSC): For complex products, the MTBF is not the only measure of the product performance once it is installed. Customer satisfaction could be better measured by tracking the 'Mean Time Between Service Calls (MTBSC)' (Hernamdez, 1993), as it would also track problems with a system that are software related, e.g., poor customer training, errors in documentation, excessive maintenance visits.

The rest of the paper is organised through a literature review below to trace the past developments standing in the area, followed by a description of our own study, its composition and development of the measurable constructs. Thereafter, we report the results of our study and our analyses of the results that came our way. We close the discussion in the conclusion section.

\section{LITERATURE REVIEW}

"Why a product sales determine how it should be sold?". This was long known informally since the ages of mercantilism. But formal businesses in later years needed its specific advocacy in management literature (Levitt, 1960) to hear the core call of trade to put the purpose before the product. This call is relevant even in recent times. '... Intangibility affects sales appeal of both intangible and tangible products. ...Packaging is one common tool. ...No 
matter how diligently designed in advance and carefully constructed, they (the giant turbines that weigh tons) will fail or disappoint if installed or used incorrectly (Levitt, 1981).' Value of the product is required to be protected and communicated long through the product's procurement and consumption stage. Whereas the product construction remains an area of manufacturing operations management, soon after begins the reign of service operations management. Their ways differ and require distinctly different approaches. The post-production operations, although are carried out and managed in firms as pseudomanufacturing by specialists of manufacturing, require their handling essentially as services. Servitisation of the postproduction operations stands to permit customer order decoupling for assuring them efficiency and responsiveness variously for goods-based supply and service-based supply, via managing those operations by either internally or engaging service associates, in the product supply chain (Vandermerwe et Rada, 1988; Wikner, 2012). Servitisation of business is meant for manufacturing firms adopting customer oriented strategy of providing 'goods, services, support, self-service and knowledge' (Baines et al., 2009).

Selling of products is selling as well some services along with. Parts of the post-production services, like logistical services, are either separately generated by the plant, or purchased by the producer in the plant from outsourced partners, for their productisation - standardising and identifying as service products for costing and trade and transferring the costs to the customer by building the component in the selling price; and some parts are directly paid for by the customers as and when those are necessitated in the value chain. Companies can keep those for them which bring competitive edge and outsource the remaining to associates (Quinn, 1990). Products come out of the value stream carrying the design intent. When the intent was goods, it sold itself by goods-dominant logic; and by service-dominant logic when the intent assumed the means of solutions, efforts went on to 'defining, designing and delivering solutions' (Sawhney, 2006). Carrying product value unhindered to the market and supporting the value-construct in the aftermarket became the winning propositions (Cohen et al., 2006). Although merit of the service-dominant logic 'of viewing the customer ... as a collaborative partner who co-creates (product-) value with the firm ...' is well founded (Lusch et al., 2007), the ServiceDelivery practices in turn call for specific attention. Strategic business practices of firms advise alignment of firm's skill portfolio for extending the service-dominant purpose (Kohen et al., 2012).

This paper, in turn, proposes bringing to alignment of a portfolio of post-production servitised operations for competitive advantage. Servitisation of post-production operations with possibilities of their productisation for trade and transfer costing are viewed this way here for the first time to our knowledge. We describe the Study in the next section followed by presenting the results and analyses.

\section{THE STUDY}

With these developments standing in the perspective, a field study was undertaken during an academic immersion project in automobile production business over a 5-month period to compare the practices on Post-Production premarket functions, Product Installation, and Product Liabilities \& Quality cost elements in four front-line Indian automobile manufacturing firms, namely AMUL, BHSCIL, CGMI and DTM ( $P C B U)$, based on their respective market shared in Indian passenger car segments in the previous year. At the outset, a preliminary frame of reference was drawn by processmapping of the three respective operation segments in order. Based on the process-mapping exercise, the inquiry went on to developing a portfolio of post-production operations and their measurable characteristics for management of the value-delivery process. These dimensions were then cross-verified with the industry experts for their expanse and reasonability. We report below the segment-wise dimensions so identified.

\subsection{Dimensions of Post-Production Functions}

1. (a) Handling and storage of finished goods (FG) to prevent damages of deterioration of products; (b) Packaging and delivery of finished goods to prevent damage or deterioration until delivery up to destination;

2. Audit of quality of FG in storage, packaging and delivery to reveal unsatisfactory storage and packaging;

3. Stores layout with secure stock areas and proper aisle widths/bays for movement and storage of FG;

4. Codification, identification, indexing of material from initial receipt through delivery to destination

5. (a) Implemented stock control processes;

(b) Authorization of receipt \& dispatch of material to and from storage areas;

6. Design of packaging materials and methods based on rigors of transport and mock-tests;

7. Packaging marked by identification labels and tags from production through handling, storage, and delivery;

8. Availability of instructions with associates and depots for handling and storage;

9. Loss in Handling \& Storage;

10. Loss in Transport. 


\subsection{Dimensions of Product Installation and Servicing}

1. Procedure and systems for service in terms of after-market services (AMS), product support and logistics back-up;

2. Facilities \& subcontractors for installation;

3. Installation manuals with checklists for staff;

4. Staff knowledge and skills in troubleshooting

5. Service duration beyond target time traceable to Design;

6. Service duration beyond target time traceable to Manufacturing;

7. Service duration beyond target time traceable to installation stage;

8. Service duration beyond target time traceable to non-availability of service-hands;

9. Service duration beyond target time traceable to non-availability of spares;

10. Returns from sites during installation.

\subsection{Dimensions of Customer Feedback, Servicing \&} Satisfaction, Product Liability \& Quality Costs Elements

1. Customer returns and complaints within and outside warranty;

2. Compilation of feedback from post installation servicing to customer;

3. Feedback to functional group in plant by Traceability data;

4. Training and awareness programme for customers on use and maintenance of product;

5. Instruction manual for handling to prevent unintended user error and misinterpretation by customer;

6. Delivery Safety, environmental and ergonomic tests on products before final delivery to customers;

7. (a) Measures for customer satisfaction;

(b) Mechanism to settle disputes with / claims from customers;

8. In-warranty returns/complaints from customers;

9. Out-of-warranty returns/complaints from customers;

10. (a) Quantify quality failure costs;

(b) Internal failure costs (scrap/rework etc.);

(c) External failure costs (warranty costs).
Because of the sensitive nature of the evidential quantitative company field-data attracting the provisions of official secrecy, it was not permissible for their sharing with outside world. A comparative study was therefore undertaken on the perceptual orientation of management and staff of these companies on these ten select critical quality elements/dimensions in each category of PostProduction pre-market functions, Product Installation, and Product Liabilities \& Quality cost elements for deriving the opportunities of improvement in the practices of last mile connectivity with customers in the sampled companies. A total of 68 sample respondents from four passenger car companies were administered a questionnaire with 10 dimensions on each variable viz. Post-Production functions, Product Installation, and Product Liabilities \& Quality cost elements as shown in Table 1. Care was taken while selecting the respondents that they belonged to strategic management levels, with strong understanding of companywide prevalent quality documentations. With relation to these aspects, close-ended questions with five (Likert scale) choice options were majorly framed. Some questions were with dichotomous options and some had ratio scale options. Descriptive statistics are used for the analysis of the collected data. The reliability for questionnaires, determined by computing Cronbach- $\alpha$ using SPSS, came out to be 0.76 .

Table 1. Categorization of Respondents With Respect to Variables.

\begin{tabular}{|l|c|c|c|c|}
\hline \multirow{2}{*}{$\begin{array}{c}\text { Element/Variable of TQM under } \\
\text { study }\end{array}$} & \multicolumn{4}{|c|}{ Number of Respondents } \\
\cline { 2 - 5 } & AMUL & BHSCIL & CGMI & DTM \\
\hline $\begin{array}{l}\text { Post-Production Function- } \\
\text { Handling, Storage, Packaging, }\end{array}$ & 5 & 5 & 5 & 5 \\
\hline $\begin{array}{l}\text { Preservation \& Delivery. } \\
\text { Product Installation \& Servicing. }\end{array}$ & 6 & 6 & 6 & 6 \\
\hline $\begin{array}{l}\text { Customer feedback, Servicing } \\
\text { and Satisfaction; Product Liability } \\
\text { and Quality cost elements. }\end{array}$ & 6 & 6 & 6 & 6 \\
\hline
\end{tabular}

\section{RESULTS AND ANALYSIS}

\subsection{Post-Production Functions: Handling, Storage, Packaging, Preservation \& Delivery}

Results in Table 2 indicate that all the sample companies claim to have proper handling and storage system of finished goods (FG) to prevent damages or deterioration of products. They also claim to be outstanding to have proper delivery of finished goods to prevent damage or deterioration until delivery up to destination of customer. These companies ensure (generally, i.e. $\geq 75 \%$ ) audit of quality of $F$ in storage and delivery. All companies claim ( $\geq 78 \%$ ) to have properly laid out stores with secure stock areas and proper aisle-width/bays for movement and handling of FG's. All companies report to have proper codification, identification and indexing of material, BHSCIL and DTM also report use of IT-based working system. 
Table 2. Post-Production Functions

\begin{tabular}{|c|c|c|c|c|}
\hline \multirow[b]{2}{*}{ Dimension } & \multirow[b]{2}{*}{ Company } & \multirow[b]{2}{*}{$n$} & \multicolumn{2}{|c|}{ Sample result (score) } \\
\hline & & & $\frac{\text { Mean }}{(x)}$ & $\begin{array}{c}\text { Standard } \\
\text { Deviation, s }\end{array}$ \\
\hline \multirow{5}{*}{$\begin{array}{l}\text { Handling and storage } \\
\text { of finished goods (FG) } \\
\text { to prevent damages } \\
\text { of deterioration of } \\
\text { products }\end{array}$} & AMUL & 6 & 0.7917 & 0.10 \\
\hline & BHSCIL & 6 & 0.9167 & 0.13 \\
\hline & CGMI & 6 & 1.0000 & 0.00 \\
\hline & DTM & 6 & 0.9583 & 0.10 \\
\hline & Total & 24 & 0.9167 & 0.12 \\
\hline \multirow{5}{*}{$\begin{array}{l}\text { Packaging and delivery } \\
\text { of finished goods } \\
\text { to prevent damage } \\
\text { or deterioration } \\
\text { until delivery up to } \\
\text { destination }\end{array}$} & AMUL & 6 & 0.7500 & 0.00 \\
\hline & BHSCIL & 6 & 0.9583 & 0.10 \\
\hline & CGMI & 6 & 00.9167 & 0.13 \\
\hline & DTM & 6 & 0.8750 & 0.21 \\
\hline & Total & 24 & 0.8750 & 0.15 \\
\hline \multirow{5}{*}{$\begin{array}{l}\text { Audit of quality of FG } \\
\text { in storage, packaging } \\
\text { and delivery to reveal } \\
\text { unsatisfactory storage } \\
\text { and packaging }\end{array}$} & AMUL & 6 & 0.7500 & 0.00 \\
\hline & $\mathrm{BHSCIL}$ & 6 & 0.8750 & 0.21 \\
\hline & CGMI & 6 & 0.9167 & 0.21 \\
\hline & DTM & 6 & 0.8750 & 0.14 \\
\hline & Total & 24 & 0.8542 & 0.16 \\
\hline \multirow{5}{*}{$\begin{array}{l}\text { Stores layout with } \\
\text { secure stock areas and } \\
\text { proper aisle widths/ } \\
\text { bays for movement and } \\
\text { storage of FG }\end{array}$} & AMUL & 6 & 0.7917 & 0.10 \\
\hline & BHSCIL & 6 & 0.8333 & 0.20 \\
\hline & CGMI & 6 & 0.8750 & 0.21 \\
\hline & DTM & 6 & 0.7917 & 0.19 \\
\hline & Total & 24 & 0.8229 & 0.17 \\
\hline \multirow{5}{*}{$\begin{array}{c}\text { Codification, } \\
\text { identification, indexing } \\
\text { of material from initial } \\
\text { receipt through delivery } \\
\text { to destination }\end{array}$} & AMUL & 6 & 0.7917 & 0.10 \\
\hline & BHSCIL & 6 & 0.8333 & 0.13 \\
\hline & CGMI & 6 & 0.8333 & 0.20 \\
\hline & DTM & 6 & 0.9167 & 0.13 \\
\hline & Total & 24 & 0.8438 & 0.14 \\
\hline \multirow{5}{*}{$\begin{array}{l}\text { Implemented stock } \\
\text { control processes }\end{array}$} & AMUL & 6 & 0.2500 & 0.00 \\
\hline & $\mathrm{BHSCIL}$ & 6 & 0.7917 & 0.19 \\
\hline & CGMI & 6 & 0.1667 & 0.13 \\
\hline & DTM & 6 & 1.5417 & 1.7 \\
\hline & Total & 24 & 0.6875 & 0.98 \\
\hline \multirow{5}{*}{$\begin{array}{l}\text { Authorization of receipt } \\
\& \text { dispatch of material to } \\
\text { and from storage areas }\end{array}$} & AMUL & 6 & 0.8333 & 0.13 \\
\hline & BHSCIL & 6 & 0.9583 & 0.10 \\
\hline & CGMI & 6 & 0.7917 & 0.10 \\
\hline & DTM & 6 & 0.8333 & 0.20 \\
\hline & Total & 24 & 0.8542 & 0.15 \\
\hline \multirow{5}{*}{$\begin{array}{l}\text { Design of packaging } \\
\text { materials and methods } \\
\text { based on rigors of } \\
\text { transport and mock- } \\
\text { tests }\end{array}$} & AMUL & 6 & 0.7500 & 0.00 \\
\hline & BHSCIL & 6 & 0.9167 & 0.13 \\
\hline & CGMI & 6 & 0.9167 & 0.13 \\
\hline & DTM & 6 & 0.4167 & 0.13 \\
\hline & Total & 24 & 0.7500 & 0.23 \\
\hline
\end{tabular}

\begin{tabular}{|c|c|c|c|c|}
\hline \multirow{5}{*}{$\begin{array}{l}\text { Packaging marked by } \\
\text { identification labels and } \\
\text { tags from production } \\
\text { through handling, } \\
\text { storage, and delivery }\end{array}$} & AMUL & 6 & 0.8333 & 0.13 \\
\hline & BHSCIL & 6 & 0.8750 & 0.21 \\
\hline & CGMI & 6 & 0.8750 & 0.14 \\
\hline & DTM & 6 & 0.8750 & 0.14 \\
\hline & Total & 24 & 0.8646 & 0.15 \\
\hline \multirow{5}{*}{$\begin{array}{c}\text { Availability of } \\
\text { instructions with } \\
\text { associates and depots } \\
\text { for handling and storage }\end{array}$} & AMUL & 6 & 0.7917 & 0.10 \\
\hline & BHSCIL & 6 & 0.9583 & 0.10 \\
\hline & CGMI & 6 & 0.9167 & 0.13 \\
\hline & DTM & 6 & 0.7917 & 0.19 \\
\hline & Total & 24 & 0.8646 & 0.15 \\
\hline \multirow{5}{*}{$\begin{array}{c}\text { Loss in Handling \& } \\
\text { Storage }\end{array}$} & AMUL & 6 & 0.2917 & 0.10 \\
\hline & BHSCIL & 6 & 0.7500 & 0.00 \\
\hline & CGMI & 6 & 0.4583 & 0.10 \\
\hline & DTM & 6 & 0.7500 & 0.00 \\
\hline & Total & 24 & 0.5625 & 0.21 \\
\hline \multirow{5}{*}{ Loss in Transport } & AMUL & 6 & 0.2917 & 0.10 \\
\hline & BHSCIL & 6 & 0.6250 & 0.14 \\
\hline & CGMI & 6 & 0.2917 & 0.10 \\
\hline & DTM & 6 & 0.7083 & 0.19 \\
\hline & Total & 24 & 0.4792 & 0.23 \\
\hline
\end{tabular}

From the results in the Table 2, it is seen that selected companies claims to ensure properly authorize receipt and dispatch of materials to and from storage areas. AMUL, $\mathrm{BHSClL}$, and CGMI claims ( $\geq 75 \%$ ) to have proper design of packaging materials and methods based on rigors of transport but DTM is poor (40\%) in this dimension. All companies generally ensure proper marking of FGs by labels and claim to be outstanding ( $\geq 80 \%)$ in making available instructions with customers and depots for handling and storage. Damages during storage and handling reported by sample companies are as under:

$\begin{array}{ll}\text { AMUL } & 1-2 \% \\ \text { BHSCIL } & 5-10 \% \\ \text { CGMI } & 1-4 \% \\ \text { DTM } & 5-10 \%\end{array}$

Percentage loss during transport:

$\begin{array}{ll}\text { AMUL } & 1-2 \% \\ \text { BHSCIL } & 5-7 \% \\ \text { CGMI } & 1-2 \% \\ \text { DTM } & 5-9 \%\end{array}$

From the results (Table 5) of ANOVA test, it is concluded, that there is no significant difference of Post-Production Function (Handling, Storage, Packaging, Preservation \&Delivery) variable in the four sample companies. However the results (Table 8) based on Independent $t$-test revealed that there is no significant difference between AMUL \& DTM 
Brazilian Journal of Operations \& Production Management

Volume 14, Número 1, 2017, pp. 126-135

DOI: 10.14488/BJOPM.2017.v14.n1.a14

(PCBU), BHSCIL \& CGMI, CGMI \& DTM (PCBU), and CGMI \& DTM (PCBU) for Post-Production Function (Handling, Storage, Packaging, Preservation \& Delivery), whereas significant difference between AMUL \& BHSCIL, and AMUL \& CGMI is indicated from the same results.

We note that the use of advance stock-control system needs to be implemented properly by AMUL and CGMI in order to have integrated codification, identification, indexation, stock control and replenishment systems for materials. DTM needs to improve its design of packaging material and methods with regard to absorbing the rigors of transport so as to reduce the damages to products while transportation. There is much scope for improvement in packaging system and its integration with modes of transportation and delivery in most companies across all industries. The extent of damage during storage and transit needs to be further decreased especially in BHSCIL and DTM where it is at $5-10 \%$. There is a need to validate new packaging materials and methods through mock-up tests, etc. Unitisation of loads for packaging also needs to be implemented in a big way to eliminate in-transit damages and conform to international standard material handling, traffic and transportation requirements particularly in view of the requirement of multi-modal transportation.

\subsection{Product Installation \& Servicing}

All companies have systems and procedures for specified service requirements for customers in terms of after-market service (AMS), product support and logistic backup (Table 3). These companies also claimed that they had necessary facilities and capable subcontractors for installation. Written installation manuals for service staff and had check lists for inspection and test before, during and after installation are available in all the companies. AMUL, BHSCIL, and DTM reported that they had qualified service staff in terms of product knowledge and skills in troubleshooting and repairs however CGMI rarely (45\%) uses qualified service staff. Installation/ servicing activities rarely stretch beyond committed time due to problems traceable to design stage in all the companies. Sometimes, installation/servicing activities stretch beyond committed time due to problems traceable to manufacturing stages in AMUL whereas this rarely happens at BHSCIL, CGMI, and DTM. In AMUL installation/ servicing activities sometimes stretch beyond time due to problems related to installation stage itself, non-availability of service personnel, and non-availability of service spares, however, it rarely happen in other sample companies. Percent returns from the sites during installation in the sample companies is as under:

$\begin{array}{ll}\text { AMUL } & <1 \% \\ \text { BHSCIL } & 1-2 \% \\ \text { CGMI } & 0 \% \\ \text { DTM } & 3-5 \%\end{array}$

Table 3. Product Installation and Servicing

\begin{tabular}{|c|c|c|c|c|}
\hline \multirow[b]{2}{*}{ Dimension } & \multirow[b]{2}{*}{ Company } & \multirow[b]{2}{*}{$\mathbf{n}$} & \multicolumn{2}{|c|}{ Sample Result (score) } \\
\hline & & & $\frac{\text { Mean }}{(x)}$ & $\begin{array}{c}\text { Standard } \\
\text { Deviation, s }\end{array}$ \\
\hline \multirow{5}{*}{$\begin{array}{c}\text { Procedure and } \\
\text { systems for service } \\
\text { in terms of after- } \\
\text { market services } \\
\text { (AMS), product } \\
\text { support and logistics } \\
\text { back-up }\end{array}$} & AMUL & 6 & 0.7917 & 0.10 \\
\hline & BHSCIL & 6 & 0.7500 & 0.22 \\
\hline & CGMI & 6 & 0.7500 & 0.00 \\
\hline & DTM & 6 & 0.8750 & 0.21 \\
\hline & Total & 24 & 0.7917 & 0.16 \\
\hline \multirow{5}{*}{$\begin{array}{l}\text { Facilities \& } \\
\text { subcontractors for } \\
\text { installation }\end{array}$} & AMUL & 6 & 0.7917 & 0.10 \\
\hline & BHSCIL & 6 & 0.8333 & 0.20 \\
\hline & CGMI & 6 & 0.7083 & 0.10 \\
\hline & DTM & 6 & 0.9167 & 0.13 \\
\hline & Total & 24 & 0.8125 & 0.15 \\
\hline \multirow{5}{*}{$\begin{array}{l}\text { Installation manuals } \\
\text { with checklists for } \\
\text { staff }\end{array}$} & AMUL & 6 & 0.7500 & 0.00 \\
\hline & BHSCIL & 6 & 1.0000 & 0.00 \\
\hline & CGMI & 6 & 0.7917 & 0.10 \\
\hline & DTM & 6 & 1.0000 & 0.00 \\
\hline & Total & 24 & 0.8854 & 0.13 \\
\hline \multirow{5}{*}{$\begin{array}{l}\text { Staff knowledge } \\
\text { and skills in } \\
\text { troubleshooting }\end{array}$} & AMUL & 6 & 0.7500 & 0.00 \\
\hline & BHSCIL & 6 & 0.8333 & 0.13 \\
\hline & CGMI & 6 & 0.4583 & 0.10 \\
\hline & DTM & 6 & 0.9167 & 0.13 \\
\hline & Total & 24 & 0.7396 & 0.20 \\
\hline \multirow{5}{*}{$\begin{array}{l}\text { Service duration } \\
\text { beyond target time } \\
\text { traceable to Design }\end{array}$} & AMUL & 6 & 0.4167 & 0.13 \\
\hline & BHSCIL & 6 & 0.4583 & 0.25 \\
\hline & CGMI & 6 & 0.1667 & 0.13 \\
\hline & DTM & 6 & 0.3750 & 0.14 \\
\hline & Total & 24 & 0.3542 & 0.19 \\
\hline \multirow{5}{*}{$\begin{array}{l}\text { Service duration } \\
\text { beyond target } \\
\text { time traceable to } \\
\text { Manufacturing }\end{array}$} & AMUL & 6 & 0.4167 & 0.13 \\
\hline & BHSCIL & 6 & 0.2917 & 0.19 \\
\hline & CGMI & 6 & 0.4167 & 0.13 \\
\hline & DTM & 6 & 0.3750 & 0.14 \\
\hline & Total & 24 & 0.3750 & 0.15 \\
\hline \multirow{5}{*}{$\begin{array}{l}\text { Service duration } \\
\text { beyond target } \\
\text { time traceable to } \\
\text { installation stage }\end{array}$} & AMUL & 6 & 0.5000 & 0.00 \\
\hline & BHSCIL & 6 & 0.1250 & 0.14 \\
\hline & CGMI & 6 & 0.0417 & 0.10 \\
\hline & DTM & 6 & 0.5417 & 0.19 \\
\hline & Total & 24 & 0.3021 & 0.26 \\
\hline \multirow{5}{*}{$\begin{array}{l}\text { Service duration } \\
\text { beyond target } \\
\text { time traceable to } \\
\text { non-availability of } \\
\text { service-hands }\end{array}$} & AMUL & 6 & 0.5000 & 0.00 \\
\hline & BHSCIL & 6 & 0.0833 & 0.13 \\
\hline & CGMI & 6 & 0.0417 & 0.10 \\
\hline & DTM & 6 & 0.2917 & 0.10 \\
\hline & Total & 24 & 0.2292 & 0.21 \\
\hline
\end{tabular}




\begin{tabular}{|c|c|c|c|c|}
\hline & AMUL & 6 & 0.4583 & 0.10 \\
\cline { 2 - 5 } $\begin{array}{c}\text { Service duration } \\
\text { beyond target time } \\
\text { traceable to non- } \\
\text { availability of spares }\end{array}$ & BHSCIL & 6 & 0.2083 & 0.25 \\
\cline { 2 - 5 } & CGMI & 6 & 0.7083 & 0.10 \\
\cline { 2 - 5 } & DTM & 6 & 0.2500 & 0.00 \\
\hline \multirow{4}{*}{$\begin{array}{c}\text { Returns from sites } \\
\text { during installation }\end{array}$} & Total & 24 & 0.4063 & 0.24 \\
\cline { 2 - 5 } & BMUL & 6 & 0.2917 & 0.10 \\
\cline { 2 - 5 } & CGMI & 6 & 0.0000 & 0.13 \\
\cline { 2 - 5 } & DTM & 6 & 0.5000 & 0.00 \\
\cline { 2 - 5 } & Total & 24 & 0.3021 & 0.21 \\
\hline
\end{tabular}

From results (Table 6) of ANOVA test, it is concluded that there is significant difference of Product Installation and Servicing variable in the four sample companies. From results (Table 9) of independent $t$-test, it is concluded that there is no significant difference between AMUL \& BHSCIL, AMUL \& DTM (PCBU), BHSCIL \& CGMI, and BHSCIL \& DTM (PCBU), for Product Installation and Servicing. However, there is significant difference between AMUL \& CGMI, and CGMI \& DTM (PCBU).

CGMI needs to have qualified service staff in terms of product knowledge and skills in trouble shooting and repair. AMUL need to develop a mechanism to trace these installation problems to manufacturing stage, installation stage itself, and non-availability of service personnel. CGMI and AMUL both need to tackle problem of non-availability of service-spares to improve installation servicing. For this, companies should study spare-parts consumption pattern and develop appropriate spare-parts control and replenishment policies. BHSCIL and DTM need to reduce returns from sites during installation to nil as it lessens confidence in the mind of customer. To avoid this, only perfect quality product should be delivered at the customers end in order to have defect-free installation ultimately ensuring smoother post-installation service operations.

\subsection{Customer feedback, Servicing and Satisfaction; Product Liability and Quality cost Elements}

Table 4, indicates that AMUL, BHSCIL, and DTM report that they generally record customer returns and complaints regularly with in warranty period but not outside warranty period however this practice is sometimes in CGMI. Further, AMUL, BHSCIL, and CGMI generally do compilation of feedback from post-installation servicing to customer on a monthly/quarterly/half yearly basis whereas DTM is poor in this dimension. But, all companies claim the regular practice of referral of feedback to concerned functional groups in the plant.

BHSCIL, CGMI, and DTM generally ( $\geq 75 \%$ ), carry out training and awareness programs for customers regarding use and maintenance of product but AMUL is very poor in this dimension. [This goes against the general perception held that AMUL goes aggressive in training. This may be cause of the fact that company holds sound policies in this, however in realty the dealers and their staff are perceptually taken to be very aggressive on sales then diminishing the value effort for quality consensus]. BHSCIL and DTM generally $(88 \%)$ analyse as review instruction manual for handling and give it with product to prevent unintended misuse, mishandling and misinterpretation of instructions at customers end however at AMUL and CGMI this practice is only at $50 \%$.

Table 4. Customer Feedback, Servicing \& Satisfaction, Product Liability \& Quality Costs Elements

\begin{tabular}{|c|c|c|c|c|}
\hline \multirow[b]{2}{*}{ Dimension } & \multirow[b]{2}{*}{ Company } & \multirow[b]{2}{*}{$\mathrm{N}$} & \multicolumn{2}{|c|}{ Sample result (score) } \\
\hline & & & $\frac{\text { Mean }}{(x)}$ & $\begin{array}{l}\text { Standard } \\
\text { Deviation, s }\end{array}$ \\
\hline \multirow{5}{*}{$\begin{array}{l}\text { Customer returns } \\
\text { and complaints } \\
\text { within and outside } \\
\text { warranty }\end{array}$} & AMUL & 6 & 0.7500 & 0.00 \\
\hline & $\mathrm{BHSCIL}$ & 6 & 0.8750 & 0.14 \\
\hline & CGMI & 6 & 0.6667 & 0.13 \\
\hline & DTM & 6 & 0.8750 & 0.14 \\
\hline & Total & 24 & 0.7917 & 0.14 \\
\hline \multirow{5}{*}{$\begin{array}{l}\text { Compilation of } \\
\text { feedback from } \\
\text { post installation } \\
\text { servicing to } \\
\text { customer }\end{array}$} & AMUL & 6 & 0.7083 & 0.10 \\
\hline & BHSCIL & 6 & 0.9167 & 0.13 \\
\hline & CGMI & 6 & 0.8750 & 0.14 \\
\hline & DTM & 6 & 0.5000 & 0.16 \\
\hline & Total & 24 & 0.7500 & 0.21 \\
\hline \multirow{5}{*}{$\begin{array}{c}\text { Feedback to } \\
\text { functional group } \\
\text { in plant by } \\
\text { Traceability data }\end{array}$} & AMUL & 6 & 0.7917 & 0.10 \\
\hline & BHSCIL & 6 & 0.9583 & 0.10 \\
\hline & CGMI & 6 & 0.7083 & 0.10 \\
\hline & DTM & 6 & 0.8333 & 0.13 \\
\hline & Total & 24 & 0.8229 & 0.14 \\
\hline \multirow{5}{*}{$\begin{array}{l}\text { Training and } \\
\text { awareness } \\
\text { programme for } \\
\text { customers on use } \\
\text { and maintenance } \\
\text { of product }\end{array}$} & AMUL & 6 & 0.2917 & 0.10 \\
\hline & BHSCIL & 6 & 0.9167 & 0.13 \\
\hline & CGMI & 6 & 0.7500 & 0.00 \\
\hline & DTM & 6 & 0.8750 & 0.21 \\
\hline & Total & 24 & 0.7083 & 0.28 \\
\hline \multirow{5}{*}{$\begin{array}{l}\text { Instruction manual } \\
\text { for handling } \\
\text { to prevent } \\
\text { unintended } \\
\text { user error and } \\
\text { misinterpretation } \\
\text { by customer }\end{array}$} & AMUL & 6 & 0.4583 & 0.10 \\
\hline & BHSCIL & 6 & 0.8750 & 0.14 \\
\hline & CGMI & 6 & 0.5417 & 0.10 \\
\hline & DTM & 6 & 0.8750 & 0.14 \\
\hline & Total & 24 & 0.6875 & 0.22 \\
\hline \multirow{5}{*}{$\begin{array}{l}\text { Delivery Safety, } \\
\text { environmental and } \\
\text { ergonomic tests } \\
\text { on products before } \\
\text { final delivery to } \\
\text { customers }\end{array}$} & AMUL & 6 & 0.7500 & 0.00 \\
\hline & BHSCIL & 6 & 0.9167 & 0.13 \\
\hline & CGMI & 6 & 0.9167 & 0.13 \\
\hline & DTM & 6 & 0.9583 & 0.10 \\
\hline & Total & 24 & 0.8854 & 0.13 \\
\hline
\end{tabular}


Brazilian Journal of Operations \& Production Management

Volume 14, Número 1, 2017, pp. 126-135

DOI: 10.14488/BJOPM.2017.v14.n1.a14

\begin{tabular}{|c|c|c|c|c|}
\hline \multirow{5}{*}{$\begin{array}{l}\text { Measures } \\
\text { for customer } \\
\text { satisfaction }\end{array}$} & AMUL & 6 & 1.0000 & 0.00 \\
\hline & BHSCIL & 6 & 0.6667 & 0.52 \\
\hline & CGMI & 6 & 1.0000 & 0.00 \\
\hline & DTM & 6 & 1.0000 & .00 \\
\hline & Total & 24 & 0.9167 & 0.28 \\
\hline \multirow{5}{*}{$\begin{array}{l}\text { Mechanism to } \\
\text { settle disputes } \\
\text { with / claims from } \\
\text { customers }\end{array}$} & AMUL & 6 & 1.0000 & 0.00 \\
\hline & BHSCIL & 6 & 1.0000 & 0.00 \\
\hline & CGMI & 6 & 0.0000 & 0.00 \\
\hline & DTM & 6 & 1.0000 & 0.00 \\
\hline & Total & 24 & 0.7500 & 0.44 \\
\hline \multirow{5}{*}{$\begin{array}{l}\text { In-warranty } \\
\text { returns/complaints } \\
\text { from customers }\end{array}$} & AMUL & 6 & 0.5000 & 0.00 \\
\hline & BHSCIL & 6 & 0.4167 & 0.13 \\
\hline & CGMI & 6 & 0.7500 & 0.00 \\
\hline & DTM & 6 & 0.2500 & 0.00 \\
\hline & Total & 24 & 0.4792 & 0.19 \\
\hline \multirow{5}{*}{$\begin{array}{l}\text { Out-of-warranty } \\
\text { returns / } \\
\text { complaints from } \\
\text { customers }\end{array}$} & AMUL & 6 & 0.2500 & 0.00 \\
\hline & BHSCIL & 6 & 0.5000 & 0.00 \\
\hline & CGMI & 6 & 0.7500 & 0.00 \\
\hline & DTM & 6 & 0.4583 & 0.10 \\
\hline & Total & 24 & 0.4896 & 0.19 \\
\hline \multirow{5}{*}{$\begin{array}{l}\text { Quantify quality } \\
\text { failure costs }\end{array}$} & AMUL & 6 & 1.0000 & 0.00 \\
\hline & BHSCIL & 6 & 1.0000 & .00 \\
\hline & CGMI & 6 & 0.0000 & 0.00 \\
\hline & DTM & 6 & 1.0000 & 0.00 \\
\hline & Total & 24 & 0.7500 & 0.44 \\
\hline \multirow{5}{*}{$\begin{array}{c}\text { Internal failure } \\
\text { costs (scrap/rework } \\
\text { etc.) }\end{array}$} & AMUL & 6 & 0.2500 & 0.00 \\
\hline & BHSCIL & 6 & 0.3750 & 0.14 \\
\hline & CGMI & 6 & 0.0000 & 0.00 \\
\hline & DTM & 6 & 0.2500 & 0.00 \\
\hline & Total & 24 & 0.2188 & 0.15 \\
\hline \multirow{5}{*}{$\begin{array}{l}\text { External failure } \\
\text { costs (warranty } \\
\text { costs) }\end{array}$} & AMUL & 6 & 0.2500 & 0.00 \\
\hline & BHSCIL & 6 & 0.5000 & 0.00 \\
\hline & CGMI & 6 & 0.0000 & 0.00 \\
\hline & DTM & 6 & 0.2500 & 0.00 \\
\hline & Total & 24 & 0.2500 & 0.18 \\
\hline
\end{tabular}

It is observed from the results (Table 4) that sample companies' carryout safety, environmental and ergonomic tests on products before final delivery to customer. All companies claim to have established objective determinants for customer satisfaction. Number of complaints for a number of customers in a time period is commonly used determinants in these companies. AMUL, BHSCIL, and DTM have a formal mechanism to settle disputes with customers. CGMI does not have any such mechanism. The percentage of value of in warranty and out of warranty returns/ complaints from customers in the sample companies is as under:

In-warranty:

$$
\text { AMUL } \quad 1-5 \% \quad \text { CGMI } 5-10 \%
$$

BHSCIL $1-3 \% \quad$ DTM $<1 \%$

Out of warranty:
AMUL
$<1 \%$
CGMI
$5-10 \%$
BHSCIL $\quad 1-5 \%$
DTM
$1-4 \%$

Except CGMI, all other sample companies have attempted to quantify quality failure costs, which are as under:

Internal failure costs (scrap/rework etc.)

$\begin{array}{llll}\text { AMUL } & <1 \% & \text { CGMI } & \text { N.A. } \\ \text { BHSCIL } & 1-3 \% & \text { DTM } & <1 \%\end{array}$

External failure costs (warranty costs)
AMUL $<1 \%$
CGMI
N.A.
BHSCIL $\quad 1-5 \%$
DTM
$<1 \%$

The findings from ANOVA test (Table 7) also indicate that there is significant difference of Customer Feedback, Servicing \& Satisfaction: Product Liability \& Quality cost elements in the four sample companies. Results of independent $t$-test (Table 10) indicate, that there is no significant difference between AMUL \& CGMI, and BHSCIL \& DTM (PCBU) for Customer Feedback, Servicing \& Satisfaction: Product Liability \& Quality cost elements. Whereas, significant difference between AMUL \&BHSCIL, AMUL \& DTM (PCBU), BHSCIL \& CGMI, and CGMI \& DTM (PCBU) is revealed for the same variable from the same results.

CGMI needs to develop a mechanism for compiling customer returns and complaints, and analyse them on a more frequent and regular basis, say at least on monthly basis and this should be done not only within warranty period but outside warranty period also. DTM should emphasize more on compilation of feedback from postinstallation servicing to customer on a monthly/quarterly/ half yearly basis. Though BHSCIL, CGMI, and DTM do have training and awareness programmes for customers, mostly through technical brochures and demonstrations relating to use and maintenance of product. AMUL should try to develop simple training, awareness and orientation programmes for customers regarding the product use, handling, safety, and maintenance. With product liability and consumer protection in focus, CGMI should develop formal mechanism to settle disputes with customer's out-of-courts to save the customers from harassment, inconvenience and in a speedy manner. Again this is to be done not only within warranty periods but also outside warranty periods. In most companies, in-warranty returns and complaints need to be reduced to a low level, say $0-.05 \%$ by taking appropriate actions in design, manufacturing, installation and postinstallation functions. CGMI should try to quantify quality failure costs both internal and external because what cannot be measured is difficult to improve. The internal \& external failure costs which are $1-3 \%$ and $1-5 \%$ respectively at $\mathrm{BHSCIL}$ should be reduced to say $<1 \%$. These costs of quality could be reduced by taking regular preventive and corrective actions to bring out zero defects at every stage. 
Table 5. One-Way ANOVA on the scores of Post-Production Functions

\begin{tabular}{|c|c|c|c|c|}
\hline $\begin{array}{c}\text { Company } \\
\text { Characteristic }\end{array}$ & AMUL & BHSCIL & CGMI & $\begin{array}{c}\text { PCBU, } \\
\text { DTM }\end{array}$ \\
\hline $\mathrm{N}$ & 6 & 6 & 6 & $6 *$ \\
\hline$\overline{\mathbf{x}}$ & 7.10 & 8.81 & 8.08 & 8.10 \\
\hline$\Sigma(\mathbf{x}-\mathbf{x})^{2}$ & 0.29 & 8.06 & 4.23 & 8.06 \\
\hline
\end{tabular}

\begin{tabular}{|c|c|c|c|c|}
\hline \multicolumn{5}{|c|}{ ANOVA TABLE } \\
\begin{tabular}{|c|c|c|} 
Sources of \\
Variation
\end{tabular} & $\begin{array}{c}\text { Sum of } \\
\text { squares }\end{array}$ & $\begin{array}{c}\text { Degrees of } \\
\text { freedom } \\
(\mathbf{v})\end{array}$ & $\begin{array}{c}\text { Mean } \\
\text { Square }\end{array}$ & Value of F \\
\hline $\begin{array}{c}\text { Between } \\
\text { samples }\left(\mathrm{S}_{1}{ }^{2}\right) \\
\begin{array}{c}\text { Within Samples } \\
\left(\mathrm{S}_{2}{ }^{2}\right)\end{array}\end{array}$ & 8.84 & 3 & 2.95 & 2.86 \\
\hline
\end{tabular}

Since $F_{\text {cal }}<F_{\text {tab }}(3.10)$
There is no significance difference at $5 \%$ level between sample means in Post-Production functions (Storage, Packaging, Preservation, Handling and Delivery.

Table 6. One-Way ANOVA on the scores of Product Installation and Servicing

\begin{tabular}{|c|c|c|c|c|}
\hline $\begin{array}{c}\text { Company } \\
\text { Characteristic }\end{array}$ & AMUL & BHSCIL & CGMI & $\begin{array}{c}\text { PCBU, } \\
\text { DTM }\end{array}$ \\
\hline $\mathbf{N}$ & 6 & 6 & 6 & 6 \\
\hline$\overline{\mathbf{x}}$ & 5.70 & 5.00 & 4.08 & 6.04 \\
\hline$\Sigma(\mathbf{x}-\mathbf{x})^{2}$ & 0.72 & 10.37 & 0.84 & 3.96 \\
\hline
\end{tabular}

ANOVA TABLE

\begin{tabular}{|c|c|c|c|c|}
\hline $\begin{array}{c}\text { Sources of } \\
\text { Variation }\end{array}$ & $\begin{array}{c}\text { Sum of } \\
\text { squares }\end{array}$ & $\begin{array}{c}\text { Degrees of } \\
\text { freedom } \\
(\mathbf{v})\end{array}$ & $\begin{array}{c}\text { Mean } \\
\text { Square }\end{array}$ & Value of $\mathbf{F}$ \\
\hline $\begin{array}{c}\text { Between } \\
\text { samples }\left(\mathrm{S}_{1}{ }^{2}\right)\end{array}$ & 13.28 & 3 & 4.43 & 5.61 \\
$\begin{array}{c}\text { Within Samples } \\
\left(\mathrm{S}_{2}{ }^{2}\right)\end{array}$ & 15.84 & 20 & 0.79 & \\
\hline \multicolumn{4}{|c|}{ Since $\mathrm{F}_{\mathrm{cal}}>\mathrm{F}_{\mathrm{tab}}(3.10)$}
\end{tabular}

(-) There is significance difference at $5 \%$ level between sample means in Product Installation and Servicing.

Table 7. One-Way ANOVA on the scores of Customer Feedback, Servicing \& Satisfaction; Product Liability \& Quality Costs Elements

\begin{tabular}{|c|c|c|c|c|}
\hline $\begin{array}{c}\text { Company } \\
\text { Characteristic }\end{array}$ & AMUL & BHSCIL & CGMI & $\begin{array}{c}\text { PCBU, } \\
\text { DTM }\end{array}$ \\
\hline $\mathbf{N}$ & 6 & 6 & 6 & 6 \\
\hline$\overline{\mathbf{x}}$ & 6.37 & 8.02 & 6.21 & 7.52 \\
\hline$\Sigma(\mathbf{x}-\mathbf{x})^{2}$ & 0.13 & 2.59 & 0.80 & 2.52 \\
\hline
\end{tabular}

\begin{tabular}{|c|c|c|c|c|}
\hline \multicolumn{7}{|c|}{ ANOVA TABLE } \\
\hline $\begin{array}{c}\text { Sources of } \\
\text { Variation }\end{array}$ & $\begin{array}{c}\text { Sum of } \\
\text { squares }\end{array}$ & $\begin{array}{c}\text { Degrees of } \\
\text { freedom } \\
(\mathbf{v})\end{array}$ & $\begin{array}{c}\text { Mean } \\
\text { Square }\end{array}$ & Value of F \\
\hline $\begin{array}{c}\text { Between } \\
\text { samples }\left(\mathrm{S}_{1}{ }^{2}\right)\end{array}$ & 13.95 & 3 & 4.65 & 15.50 \\
$\begin{array}{c}\text { Within Samples } \\
\left(\mathrm{S}_{2}{ }^{2}\right)\end{array}$ & 6.07 & 20 & 0.30 & \\
\hline
\end{tabular}

(-) There is significance difference at $5 \%$ level between sample means in Customer Feedback, Servicing \& Satisfaction; Product Liability \& Quality Costs.
Table 8. t-statistic for Inter-Company Comparison on Post-Production Function

\begin{tabular}{|c|c|c|c|c|}
\hline $\begin{array}{c}\text { Company } \\
\text { Groups }\end{array}$ & AMUL & BHSCIL & CGMI & $\begin{array}{c}\text { PCBU, } \\
\text { DTM }\end{array}$ \\
\hline AMUL & - & $\begin{array}{c}(-) \\
\mathrm{t}=3.25\end{array}$ & $\begin{array}{c}(-) \\
\mathrm{t}=3.66\end{array}$ & $\begin{array}{r}(+) /(-) \\
\mathrm{i}=1.90\end{array}$ \\
\hline BHSCIL & - & - & $\begin{array}{c}(+) \\
\mathrm{t}=1.14\end{array}$ & $\mathrm{t}=0.97$ \\
\hline CGMI & - & - & - & $\mathrm{t}=0.03$ \\
\hline PCBU, DTM & - & - & - & - \\
\hline
\end{tabular}

Table 9. t-statistic for Inter-Company Comparison on Product Installation and Servicing

\begin{tabular}{|c|c|c|c|c|}
\hline $\begin{array}{c}\text { Company } \\
\text { Groups }\end{array}$ & AMUL & BHSCIL & CGMI & $\begin{array}{l}\text { PCBU, } \\
\text { DTM }\end{array}$ \\
\hline AMUL & - & $\mathrm{t}=1.15$ & $t=\stackrel{(-)}{7.01}$ & $t=d^{+} .865$ \\
\hline BHSCIL & - & - & $\mathrm{t}=1.32$ & $t=1.50$ \\
\hline CGMI & - & - & - & $\left.t=5^{-}\right) 91$ \\
\hline PCBU, DTM & - & - & - & - \\
\hline
\end{tabular}

(+) Null hypothesis, that there is no significance difference between two sample means at $5 \%$ level, is accepted.

(-) Null hypothesis is not accepted. Figures below parenthesis () indicate calculated t-statistic

Table 10. t-statistic for Inter-Company Comparison on Customer Feedback, Servicing \& Satisfaction, Product Liability and Quality Costs Elements

\begin{tabular}{|c|c|c|c|c|}
\hline $\begin{array}{c}\text { Company } \\
\text { Groups }\end{array}$ & AMUL & BHSCIL & CGMI & $\begin{array}{c}\text { PCBU, } \\
\text { DTM }\end{array}$ \\
\hline AMUL & - & $\mathrm{t}=5.49$ & $\mathrm{t}=0.89$ & $\mathrm{t}=3.90$ \\
\hline BHSCIL & - & - & $\begin{array}{c}(-) \\
\mathrm{t}=5.4\end{array}$ & $\begin{array}{r}(-) \\
\mathrm{t}=1.20\end{array}$ \\
\hline CGMI & - & - & - & $\mathrm{t}=3.91$ \\
\hline PCBU, DTM & - & - & - & - \\
\hline
\end{tabular}

(+) Null hypothesis, that there is no significance difference between two sample means at $5 \%$ level, is accepted.

(-) Null hypothesis is not accepted. Figures below parenthesis () indicate calculated t-statistic.

\section{CONCLUSION}

This paper took the agenda of customer connectivity as its principal focus area for bringing out some of its operational dimensions offering opportunities for significant productivity gained around their soft spots. In spite of our inaccessibility to the techno-commercial quantitative data regarding the practices in the sample companies, our comparative measurement of the company practices in question succeeded in arriving at several intercompany gaps as a benchmark for their possible strategic interventions. A larger sample size and a wider sample base of the companies will help overcome the scale and scope limitation of the present study. Cross-industry comparison of the post-production functions can further help investigators developing a better understanding of operational means of customer connectivity improvement in the organisations and help generalising the inquiry. 


\section{REFERENCES}

Baines, T. S., Lightfoot, H. W. et Kay J. M. (2009), "Servitized manufacture: Practical challenges of delivering integrated products and services", Proc. IMechE Vol. 223 Pt. B: J. Engineering Manufacture, pp. 1207-1215.

Baines, T. S., Lightfoot, H. W. et Smart, P. (2013), "Servitization within manufacturing operations: An exploration of the impact of facilities practices", Proc. IMechE Vol. 226 Pt. B: J. Engineering Manufacture, pp. 377-380.

Baines, T. S., Lightfoot, H. W., Smart, P. et Fletcher, S. (2013), "Servitization of manufacture: Exploring the deployment and skills of people critical to the delivery of advanced services", J. Manufacturing Management, Vol. 24, No. 4, pp. 637-646.

Cohen, M. A., Agarwal, N. et Agarwal, V. (2006), "Winning in the aftermarket", Harvard Business Review, Vol. 84, No. 5, pp. 129-138.

Dingus, V. R. (1988), "Quality is exceeding customer expectations", Industrial Engineering Journal, pp. 24-25.

Hernamdez, A. (1993), "Just in Time Quality -- A practical Approach", Prentice Hall, Englewood Cliffs, New Jersey, USA. p. 95.

Johnson, M. M., (1987), "An investigation of the effects of quality determinants", in Sepehri, M. (Ed.), 'Quest for Qualit-Managing the total system', Industrial Engineering and Management Press, Norcross, Georgia, USA.

Karpen, I. O., Bove, L. et Lukas, B. A. (2012), “Linking service-dominant logic and strategic business practice: $A$ conceptual model of a service-dominant orientation", J. Service Research, Vol. 15, No. 1, pp. 21-38.

Levitt, T. (1981), "Marketing intangible products and product intangibles", Harvard Business Review, Vol. 59, No. 3, pp. 94-102.

Levitt, T. (2004), "Marketing myopia”, Harvard Business Review, Vol. 82, No. 7/8, pp. 138-149.

Lusch, R. F., Vargo, S. L. et O’Brien, M. (2007), “Competing through service: Insights from service-dominant logic", J. Retailing, Vol. 83, No.1, pp. 5-18.

Metters, R. et Vargas, V. (2000), "A typology of de-coupling strategies in mixed services", J. Operations Management, Vol. 18 , pp. 663-682.

Michel, S., Brown, S. W. et Gallan, A. S. (2008), "Servicelogic innovations: How to innovate customers, not products", California Management Review, Vol. 50, No. 3, pp. 49-65.

Möller, K., Rajala, R. et Westerlund, M. (2008), "Service innovation myopia", California Management Review, Vol. 50, No. 3, pp. 31-48..
Pal, S. S. et Jasial, S. S. (2015), “Dynamic Design for Quality for Total Quality Advantage: A Benchmarking Case Study from Indian Automobile Manufacturing Sector", Knowledge and Process Management, Wiley Online 1 March 2015, DOI: 10.1002/kpm.1464, 10p.

Quinn, J. B., Doorley, T. L. et Paquette, P. C. (1990), "Beyond Products: Services-Based Strategy", Harvard Business Review. Mar/Apr90, Vol. 68 Issue 2, pp. 58-67.

Shankar, V., Berry, L. L. et Dotzel, T. (2009), “A practical guide to combining products + services", Harvard Business Review, Vol. 87, Issue 11, pp. 95-99.

Sohal, A. S., Tay G. S. et Wirth, A. (1989), "Total Quality Control in an Asian division of a multinational Corporation", Int. J. Quality and Reliability management, Vol. 6, No. 6, pp. 60-74.

Steeples, M. M. (1992), "The corporate guide to the Malcolm Baldrige National Quality Award", Milwaukee: American Society for Quality.

Vargo, S. L. et Lusch, R. F. (2008), “From goods to service(s): Divergence and convergence of logics", Industrial Marketing Management, Vol. 37, No. 3, 2008, pp. 254-259.

Wikner, J. (2012), “A service decoupling point framework for logistics, manufacturing, and service operations", Int. J. Services Sciences, Vol. 4, No. 3/4, pp. 330-357.

Xiao-rong, J., Sui-cheng, L. et Lang, Z. (2009), "The study on the influencing factors on relationship performance in servitization of manufacturing", Proc. IEEE Computer Society, 2009 Int. Conf. Information Management, Innovation Management and Industrial Engineering, pp. 480-484. 